UDC 374.72

DOI https://doi.org/10.32782/easterneurope.26-5

\title{
CONTEMPORARY STATE OF UKRAINIAN ENTERPRISES DEVELOPMENT UNDER MODERN GLOBALIZATION CONDITIONS
}

\author{
СУЧАСНИЙ СТАН РОЗВИТКУ УКРАЇНСЬКИХ ПІДПРИЕМСТВ \\ ЗА НИНІШНІХ УМОВ ГЛОБАЛІЗАЦІї
}

\author{
Nikitina Alina \\ Candidate of Economic Sciences, Associate Professor, \\ Senior Lecturer at the Department of International Economics \\ and Management of Foreign Economic Activity, \\ Simon Kuznets Kharkiv National University of Economics \\ Zakharenko Iryna \\ Student, \\ Simon Kuznets Kharkiv National University of Economics
}

Нікітіна А.B. кандидат економічних наук, доцент, доцент кафредри міжнародної економіки та менеджменту зовнішньоекономічної діяльності, Харківський національний економічний університет імені Семена Кузнеця

Захаренко І.В. студентка, Харківський національний економічний університет імені Семена Кузнеця

The article examines the patterns of innovative transformation of the business sector of Ukraine based on statistics. Through in-depth and comprehensive analysis of scientific publications on economic development of the Ukrainian enterprises in modern conditions, the main problems of the business-sector in the economy of the country have been identified, effective methods of improving this situation have been found. The authors have built models that characterize effects, which give increased localization and outstripping growth rates of the "innovative sector", catalyzing the development of the economy. It is shown using the growth of the share of the innovative sector and the outstripping general economic dynamics of enterprises. The structure of the enterprises' complex of different production directions have been considered, with the help of which the main and side effects of the irrational usage of labor and financial resources at the enterprises have been calculated. The factors limiting business development opportunities in the Ukrainian and international markets have been highlighted. The potential for the development of enterprises has been determined and assessed. Factors of attractiveness for investing in the Ukrainian business sector have been investigated and ways to improve its condition have been suggested.

Key words: entrepreneurial activity, profit, investment, export, import, development, market, economy of Ukraine.

В статье рассматриваются закономерности инновационной трансорормации бизнес-сектора Украины на основе статистических данных. Путем глубокого и всестороннего анализа научных публикаций об экономическом развитии украинских предприятий в современных условиях, вычислены основные проблемы бизнессектора в экономике Украчны, были найдены эфффективные методы улучшения данной ситуации. Авторы построили модели, характеризующие эфрфекты, которые дают повышенную локализацию и опережающие темпы роста «инновационного сектора», катализирующего развитие экономики. Это показано на примере роста доли инновационного сектора и опережающей общеэкономической динамики предприятий. Рассмотрена структура комплекса предприятий различных направлений производства, с помощью, которой рассчитаны основные и побочные эффректы нерационального использования трудовых и фринансовых ресурсов на предприятиях. Выделены фракторы, ограничивающие возможности развития бизнеса на украинском и международном рынках. Определен потенциал развития предприятий. Исследованы фракторы привлекательности для инвестиций в украинский бизнес-сектор и предложены пути улучшения его состояния.

Ключевые слова: предпринимательская деятельность, прибыль, инвестиции, экспорт, импорт, развитие, рынок, экономика Украины. 
У статті розглянуто закономірності інноваційної трансформації бізнесового сектору України на основі статистичних даних. Шляхом поглибленого та всебічного аналізу наукових публікацій про економічний розвиток українських підприємств у сучасних умовах розглядаються основні проблеми бізнес-сектору в економіці країни, знайдені ефрективні методи покращення цієї ситуації. Автори побудували моделі, що характеризують ефекти, що дають посилену локалізацію та випереджаючі темпи зростання "інноваційного сектору", каталізуючи розвиток економіки. Це показано на основі зростання частки інноваційного сектору та випереджальної загальної економічної динаміки підприємств. Розглянуто структуру комплексу підприємств різних виробничих напрямків, за допомогою яких розраховано основні та побічні ефекти нераціонального використання трудових та фрінансових ресурсів на підприємствах. Висвітлено фрактори, що обмежують можливості розвитку бізнесу на українському та міжнародному ринках. Визначено потенціал для розвитку підприємств. Досліджено фрактори привабливості для інвестування в український бізнессектор та запропоновано шляхи покращення його стану. Актуальність розглянутої теми полягає у тому, що інтеграція економіки в світове господарство, що наразі є пріоритетним напрямком для України, повинна відбуватися за допомогою ефективних, а іноді інноваційних засобів міжнародної співпраці, серед яких вагома роль належить інвестуванню, в тому числі іноземному. Враховуючи тенденції світової економіки та останні світові події, проблема створення умов для розвитку та впровадження сучасних технологій та інноваційних продуктів є як ніколи актуальною. Крім того, ефективне управління створенням та використанням інтелектуальних ресурсів на підприємствах також важливо для забезпечення їх інноваційного розвитку. А однією з ефрективних фрорм використання іноземного капіталу виступають підприємства, що займаються інноваційною діяльністю. Саме тому інвестиційне забезпечення інноваційних підприємств України нерозривно пов'язане зі створенням ефективного механізму залучення інвестиційних ресурсів в підприємства, так само й інноваційний розвиток країни надасть конкурентні переваги в умовах сучасного європейського і світового ринків.

Ключові слова: підприємницька діяльність, прибуток, інвестиції, експорт, імпорт, розвиток, ринок, економіка України.

Introduction. The modern market economy dictates the need to constantly improve the efficiency of economic entities to ensure the competitiveness of products and the positions of the enterprise. Improving the efficiency and effectiveness of production processes is one of the urgent tasks in modern conditions.

Analysis of recent research and publications. During the whole period of market transformations, the most acute and painful problem remains the financial support of current activities and long-term economic development of agricultural enterprises as well as light industry enterprises, the machinebuilding complex and food industry enterprises. They constantly demonstrate instability and high variability of performance. Despite the fact that investment and fixed capital are constantly growing, they do not provide even a simple reproduction of fixed assets. For example, investments at the expense of all sources of financing in agriculture, hunting, forestry decreased by more than a third: from 10.9 billion UAH in the first quarter of 2019 to 7.0 billion UAH in January-March, 2020. The financial support of domestic large industrial enterprises in the form of cash and commodity loans, subcontracting, leasing, franchising are of the great importance in the financing of the above mentioned Ukrainian enterprises. The dominant directions in solving this problem are the activation of state agricultural policy and its financial component, the development and improvement of financial management of enterprises and industries as a whole.

Results. At the above and many other industrial complexes-enterprises of Ukraine, the issue of innovation is acute, because it is one of the most important indicators that characterize the innovation sphere of the country. In the presence of the prospects of EU integration and participation in the European Research Area, it is expedient for Ukraine to study and adapt the experience of the European countries, in particular those where the development of innovative enterprises takes place in conditions of limited financial resources and scientific and technological potential. In particular, in Poland the infrastructure of support for innovative enterprises is diversified, which allows to solve current problems of scientific and technological activities and to coordinate the interests of the parties in the development of small and medium enterprises.

In recent years, Ukrainian light industry enterprises have also experienced a number of problems that have led to a deterioration in their performance. At present, most of the former large light industry enterprises, which in the early 1990s supplied their products throughout the CIS, have reduced their production tenfold, and most have ceased operations altogether. This is primarily due to the unequal competitive conditions for domestic producers, due to the extremely high level of presence in the domestic market of imported light industry products. The lack of established links with markets and frequent discrimination against domestic producers in retail chains are equally important. This leads to high investment risks. Despite the above factors, light industry enterprises constantly provide a significant level of GDP production and employment. But, unfortunately, a little attention was paid to the development of 
the domestic light industry during 30 years of independence. As a result, the share of light industry in total industrial production has decreased almost 14 times: from $10.8 \%$ in 1990 to $0.8 \%$ in 2019. The industry lost more than 800 thousand workplaces. The structure of realization of light industry enterprises products as of the beginning of 2020 (JanuaryFebruary) is shown in Figure 1.

The fashion industry is one of the most perspective areas for Ukraine. It combines elements of "classic" light industry (production of fabrics, clothing and footwear) and the system of product promotion in the market (creation of brands and design houses, logistics, information and communication support). The fashion industry is a component of the creative economy, which accounts for $3.4 \%$ of world GDP, and annual growth rates in different countries range from 4.3 to $17.6 \%$.

The machine-building complex has also undergone significant structural deformations, losses of production and personnel potential, and a decrease in innovation and investment activity during the years of Ukraine's independence. The lack of modernization of the industry has led to a significant lag in its production capacity in terms of technological methods.

In the presence of the strong potential of the engineering industry, investment and consumer demand for a number of commodity items is met by imports (the share of imports in the domestic market of Ukraine in the first half of 2020 amounted to $7,808.2$ million USD, which is $13.5 \%$ less $(-1,216.0$ million USD) than for the same period last year), while domestic products are exported (the share of exports of engineering products in total sales amounted to 2,442.2 million USD in the first half of 2020 , which is $18.5 \%$ less than for the same period in 2019 (-1 034.2 million USD)). These indicators illustrate the critical level of import dependence of the domestic market of machinebuilding products.

Due to the unfavourable investment climate, foreign companies prefer to export finished machinebuilding products to Ukraine. There are few examples of foreign companies transferring production to Ukraine. One of the most recent is the agreement in 2019 on the production of a certain car series of the French company Renault by the Ukrainian plant ZAZ. According to the Ukrainian manufacturer, "Localized assembly allows us to stay in close proximity to our customers and adapt the service to market needs", the partner company claims that the Ukrainian market has high potential for them due to its location and growing interest in new cars.

In general, imports of goods in 2020 increased by as much as $9.3 \%$ - up to 23.53 billion USD.

The negative balance of foreign trade is more than 2.6 billion USD. On the one hand, the active import of goods contributes to the filling of the State Budget through the payment of duties and excises. But these funds could be obtained in another way - by developing their own production and stimulating domestic demand for domestic products. Ukrainians should prefer the products of our manufacturers, and our business should care about quality and gradually convince that their products are not worse (and in many cases even better) than, for example, equipment manufactured under well-known brands of foreign suppliers.

Food industry enterprises are one of the main system-forming components of the domestic economy. They are directly involved in ensuring the basic food security of the state, the formation of its export potential and are able to positively influence the dynamics of economic growth in Ukraine. In the total volume of processed products, the food industry is $21 \%$, its share in total GDP is $5 \%$.

Currently, the position of imports in the domestic food market is growing more rapidly: from $15 \%$ in 2015 to $20 \%$ in 2019. Among dairy products - from $6 \%$ to $11 \%$, including cheese - from $11 \%$ to $20 \%$, confectionery-from $11 \%$ to $24 \%$, vegetables - from $16 \%$ to $30 \%$. In a pandemic, this trend is gaining momentum. Imports of dairy products have tripled in the last year, vegetables by almost $70 \%$, finished meat and fish products by more than 1.5 times, processed vegetables and sugar confectionery by $25 \%$, and fresh fruit by $20 \%$. In addition, all this is happening against the background of a sharp decline in exports of the Ukrainian dairy products, sugar and confectionery from it, both raw and canned fruits and vegetables.

The data shown in Figure 2 indicate an insufficient level of innovation activity of the Ukrainian enterprises, so, in 2019 , only $20.5 \%$ of enterprises were engaged in innovation activities.

The decrease in innovation activity is caused by the lack of own funds, as well as the high cost of credit resources. The issue of the fact that almost $90 \%$ 


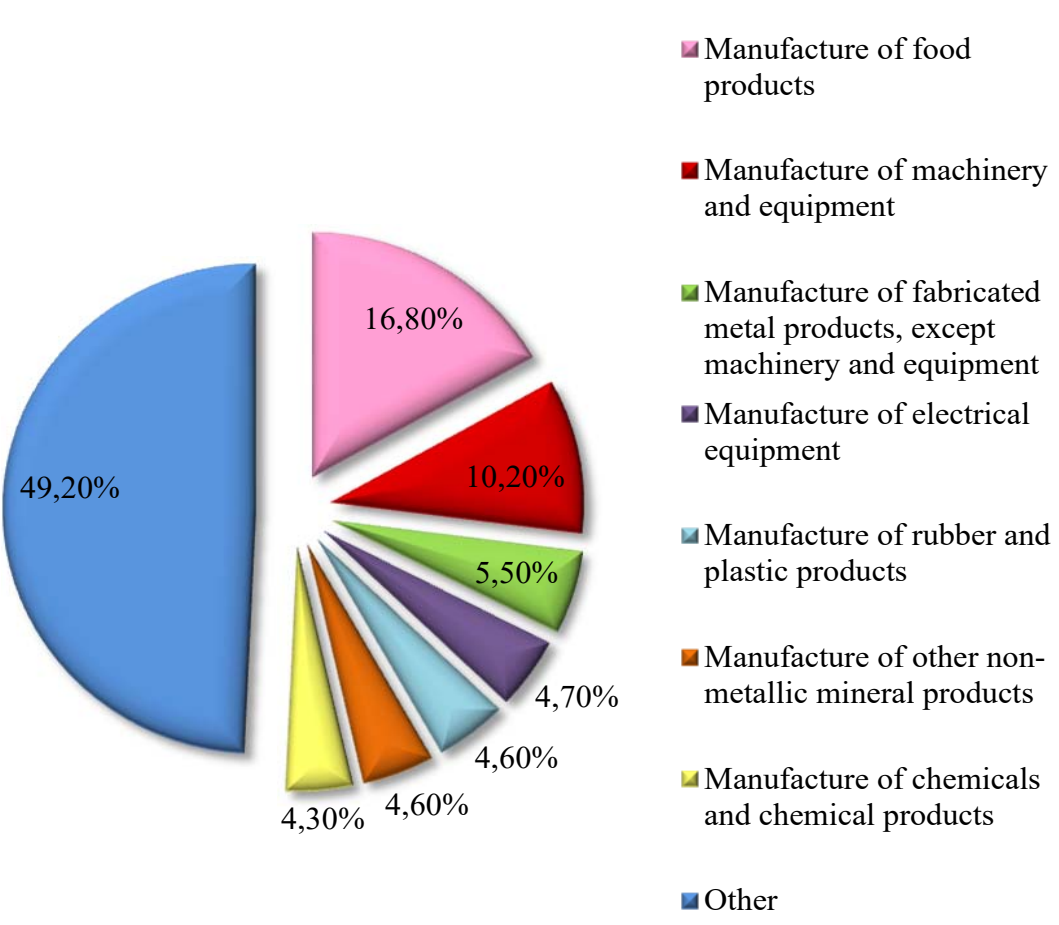

Figure 2. Structure of innovatively active industrial enterprises in terms of economic activities (\%)

of industrial enterprises do not have modern hightech and scientific support remains problematic; the number of scientific organizations engaged in technical development, as well as organizations of the design and factory sectors is decreasing; the number of specialists in the scientific and technical sphere is decreasing. Unfortunately, the Ukrainian innovation sphere remains not attractive enough for both domestic and foreign investors. This is due to the imperfection of the regulatory framework and the time duration of the return on investment.

The strategic goal for the economy of Ukraine is the formation of organizational and economic model of development of innovative small and medium enterprises as the main component of the national innovation system and the decisive force of commercialization and creation of the innovation market.

It is necessary to concentrate efforts on expansion of commer-cialization of scientific potential of scientific institutions and higher educational institutions by means of the state (regional) support of creation and development of small innovative enterprises at these organizations in the directions presented in Figure 3.

Comparing the experience of the EU and some other countries with the experience of Ukraine in this matter, it should be noted that in general, almost no instrument of innovation policy is implemented in the practice of the Ukrainian enterprises.

Among the main areas of implementation of the provisions of the Sustainable Development Strategy "Ukraine - 2021" there should be the creation of industries that implement the latest technological methods and access to domestic and foreign markets with world-class products. The result of this stage of socio-economic development should be providing competitive advantages in promising sectors where products have not been

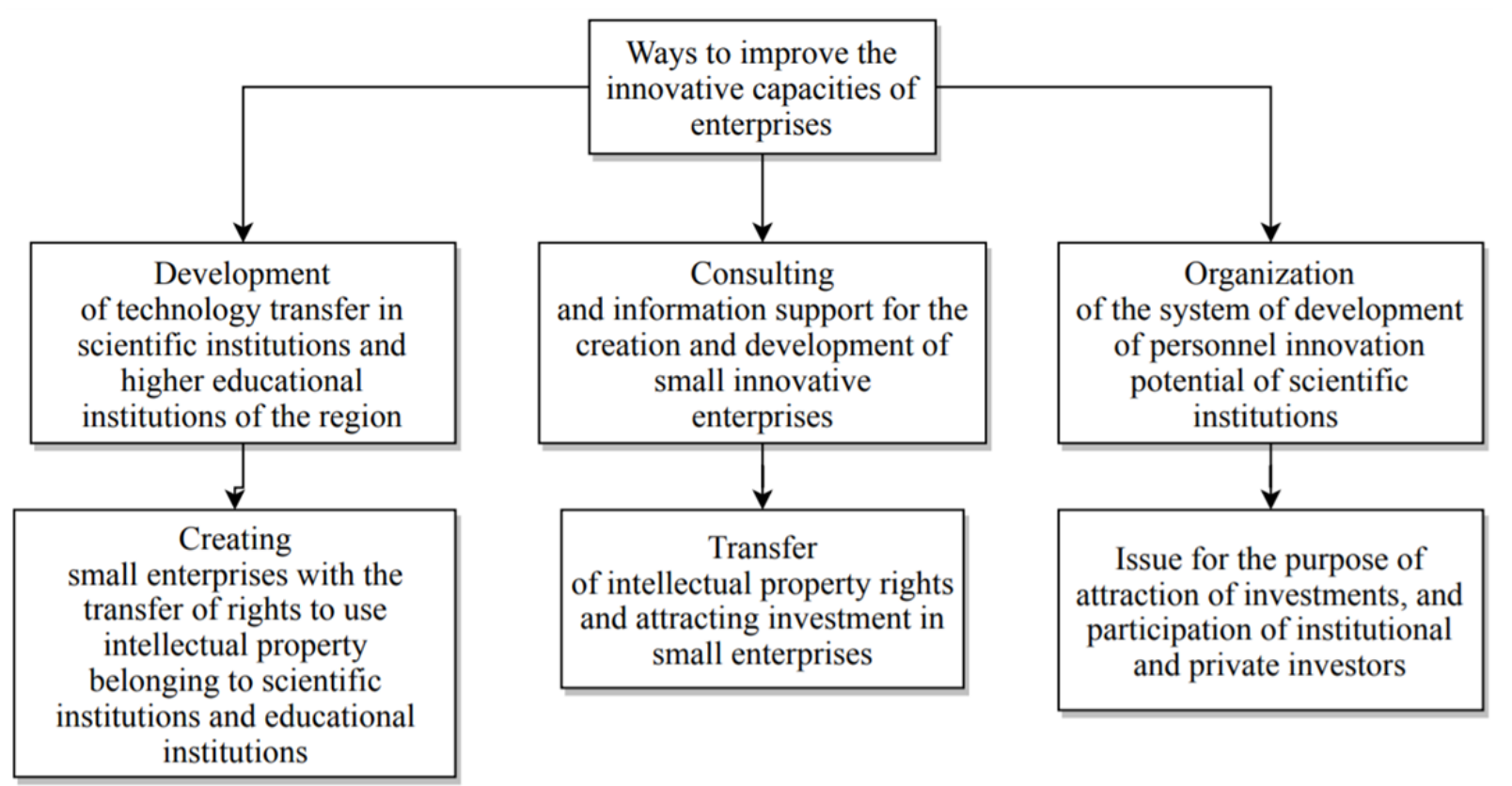

Figure 3. Ways to improve the innovative capacities of enterprises 
previously presented, and in some cases the formation of dominant demand, in which domestic knowledge-intensive products play the main role.

Conclusions. Thus, increasing the level of innovation of production potential of enterprises will improve the efficiency of its usage and ensure the competitiveness of products by reducing energy consumption, improving its consumer qualities, increase consumer demand for it at both domestic and foreign markets. That is why it is necessary to modernize production at enterprises, widely introduce new equipment and technologies to reduce material, energy and resource consumption of production and to carry out comprehensive automation and mechanization of production processes.

\section{REFERENCES:}

1. Pysarenko T.V., Kvasha T.K., Rozhkova L.V. (2020) Innovatsiina diialnist v Ukraini u 2019 rotsi [Innovative activity in Ukraine in 2019], Kyiv: UkrINTEl. (in Ukrainian)

2. Innovatsiina Ukraina 2020 [Innovative Ukraine 2020]: natsionalna dopovid (2015) / Kyiv: NAN Ukrajiny. (in Ukrainian)

3. Ministerstvo rozvytku ekonomiky, torhivli ta silskoho hospodarstva Ukrainy (2020) Eksport tovariv i posluh Ukrainy [Export of goods and services of Ukraine], Kyiv. Available at: https://www.me.gov.ua/Documents/Download?id=a4519e1d-d49f-4167-876b-1b544fae85de (accessed 11 November 2020).

4. Ministerstvo rozvytku ekonomiky, torhivli ta silskoho hospodarstva Ukrainy (2020) Import tovariv i posluh Ukrainy [Import of goods and services of Ukraine], Kyiv. Available at: https://www.me.gov.ua/Documents/Download?id=f7744e11-018c-4fb9-aa74-b94e699753c1 (accessed 11 November 2020).

5. Zianko V.V. (2008) Innovatsiine pidpruiemnytstvo: sutnist, mekhanizmy i formy rozvytku: monohrafiia [Innovative entrepreneurship: essence, mechanisms and forms of development],Vinnytsia: Universum. (in Ukrainian)

6. Hovorukha Zh.A. (2007) Pytannia rozvytku innovatsiinoi diialnosti pidpryiemstv Ukrainy [Issues of innovative activity development of Ukrainian enterprises]. Current economic problems, vol. 8, no. 74, pp. 107-115.

7. Heiets V.M., Semynozhenko V.P. (2006) Innovatsiini perspektyvy Ukrainy [Innovative prospects of Ukraine]. Kharkiv: Konstant. (in Ukrainian)

8. Kovalchuk S.V. (2012) Suchasnyi stan innovatsiinoho rozvytku promyslovykh pidpryiemstv Ukrainy [The current state of innovative development of industrial enterprises of Ukraine]. Ekonomist, vol. 10, no. 312, pp. $27-32$.

\section{БІБЛІОГРАФІЧНИЙ СПИСОК:}

1. Писаренко Т.В., Кваша Т.К., Рожкова Л.В. Інноваційна діяльність в Україні у 2019 році : монограсрія. Київ : УкрIHTEI, 2020. 45 с.

2. Інноваційна Україна. 2020 : національна доповідь / НАН України. Київ, 2015. 336 с.

3. Експорт товарів і послуг України / Міністерство розвитку економіки, торгівлі та сільського господарства України. URL: https://www.me.gov.ua/Documents/Download?id=a4519e1d-d49f-4167-876b-1b544fae85de (дата звернення: 11.10.2020).

4. Імпорт товарів і послуг України / Міністерство розвитку економіки, торгівлі та сільського господарства України. URL: https://www.me.gov.ua/Documents/Download?id=f7744e11-018c-4fb9-aa74-b94e699753c1 (дата звернення: 11.10.2020).

5. Зянько В. В. Інноваційне підприємництво: сутність, механізми і форми розвитку : монографія. Вінниця : Універсум, 2008. 397 с.

6. Говоруха Ж.А. Питання розвитку інноваційної діяльності підприємств України. Актуальні проблеми економіки. 2007. № 8 (74). С. 107-115.

7. Геєць В. М., Семиноженко В. П. Інноваційні перспективи України. Харків : Констант, 2006. 272 с.

8. Ковальчук С. В. Сучасний стан інноваційного розвитку промислових підприємств України. Економіст : науковий та громадсько-політичний журнал. 2012. № 10 (312). С. 27-32. 